\title{
PRODUCTION OF PARTICLEBOARD FROM DISCARDED FURNITURE1
}

\author{
Esoline Helena Cavalli Zamarian ${ }^{2 *}$, Setsuo Iwakiri ${ }^{3}$, Rosilani Trianoski ${ }^{3}$ and Carlos Eduardo Camargo de
} Albuquerque ${ }^{3}$

\footnotetext{
${ }^{1}$ Received on 02.07.2016 accepted for publication on 21.06.2017.

${ }^{2}$ Universidade Tecnológica Federal do Paraná, Departamento de Desenho Industrial, Curitiba - Brasil. E-mail: <esolinezamarian@utfpr.edu.br>.

${ }^{3}$ Universidade Federal do Paraná, Departamento de Engenharia e Tecnologia Florestal, Curitiba - Brasil. E-mail: <setsuo@ufpr.br>, $<$ rosilani@ufpr.br> and <camargo@ufpr.br>.

*Corresponding author.
}

\begin{abstract}
This research aims to evaluate the quality of particleboard produced with particles generated from discarded furniture, both in its pure form or mixed with industrial particles of Pinus. The material was collected in the region of Curitiba City (Paraná) in the form of chips processed in an industrial chipper of a company specialized in waste wood recycling. The experimental plan consisted in producing panels with $10 \%, 25 \%, 50 \%$ and $75 \%$ of particles obtained from discarded furniture mixed with particles of Pinus, and panels with $100 \%$ of such materials. Panels were produced with nominal density of $0,70 \mathrm{~g} / \mathrm{cm}^{3}$, using the urea-formaldehyde resin in a proportion of $10 \%$ solids - dry basis weight of the particles and $1 \%$ paraffin emulsion. The panels were pressed with a specific pressure of $4,0 \mathrm{MPa}$, temperature of $140^{\circ} \mathrm{C}$ and pressing time of 10 minutes. The results of internal bond met the requirements of the standard EN 312, which indicates that there was an adequate bonding of these particles obtained from discarded furniture. The results of physical and mechanical properties of the panels demonstrated the feasibility of using particles from discarded furniture when producing particleboard, with the possibility of full use of these particles from waste without mixing it with industrial particles of Pinus free from contamination.
\end{abstract}

Keywords: Recycling of materials; Wood particles; Furniture waste.

\section{PRODUÇÃO DE PAINÉIS AGLOMERADOS A PARTIR DE MÓVEIS DESCARTADOS}

\begin{abstract}
RESUMO-O objetivo deste trabalho foi avaliar a qualidade de painéis aglomerados produzidos com partículas geradas a partir de móveis descartados, na forma pura e em mistura com partículas industriais de Pinus. O material foi coletado na região de Curitiba-PR na forma de cavacos processados num triturador industrial de uma empresa especializada em reciclagem de resíduos de madeira. O plano experimental consistiu na produção de painéis com 10\%, 25\%, 50\% e 75\% de partículas de descartes de móveis com partículas de Pinus, além de painéis com 100\% destes materiais. Foram produzidos painéis com densidade nominal de $0,70 \mathrm{~g} / \mathrm{cm}^{3}$, utilizando a resina ureia-formaldeído na proporção de $10 \%$ de sólidos - base peso seco das partículas, e, 1\% de emulsão parafinica. Os painéis foram prensados com pressão específica de 4,0 MPa, temperatura de $140^{\circ} \mathrm{C}$ e tempo de prensagem de 10 minutos. Os resultados de ligação interna atenderam aos requisitos da norma EN 312, sendo indicativo de que houve uma colagem adequada destas partículas provenientes de descartes de móveis. Os resultados das propriedades fisicas e mecânicas dos painéis demonstraram a viabilidade de uso de partículas provenientes de descartes de móveis para a produção de painéis aglomerados, com a possibilidade de uso integral destas partículas provenientes de resíduos sem a mistura com partículas industriais de Pinus livres de contaminação.
\end{abstract}

Palavras-chave: Reciclagem de materiais; Painéis particulados; Resíduos de móveis. 


\section{INTRODUCTION}

The main source of wood used on the production of particleboards in Brazil comes from planted forests, with Pinus and Eucalyptus being the most used species (Iwakiri et al., 2002). Particleboards industries use wood in the form of thin logs from slabs, or also chips generated from the reprocessing of sawmills and rolling mills.

The use of residues of wood products at the end of their life cycle is not yet performed in Brazil for the manufacture of particleboards, although it is one of the main sources of raw materials in developed countries. However, in recent years, studies on the potential use of various types of wood residues and wood products on the production of particleboards have been objects of some researchers in Brazil. Weber and Iwakiri (2015) evaluated the feasibility of using residues from the processing of plywood, chipboard and MDF in the production of particleboards; Azambuja (2015) carried out studies on the potential of using construction and demolition waste as raw material in the production of particleboards; Iwakiri et al. (2012) evaluated the quality of particleboards produced with sawmill waste from the Amazon region. The researchers found satisfactory results for the use of these residues in the production of particleboards, indicating it is possible to incorporate them into the raw material matrix for these industries.

Mickleburgh and Magin (2003) report that the reprocessing of wood waste from furniture, packaging and demolition wood may be a viable alternative on the production of particle wood panels. The process used to generate chips from various residues using special chippers is simple, efficient, and inexpensive, being technically and economically interesting to add value to the waste and provide supplies to the particleboards industries.

The use of particleboards is directly associated with their physical and mechanical properties. The technical restrictions for its use and the application of panels involve characteristics such as mechanical strength, dimensional stability, surface uniformity, machinability, resistance to fixing screws, among others. The effects of wood raw material characteristics on the properties of particleboards are described by Maloney (1993) and Moslemi (1974) and are mainly related to the density, $\mathrm{pH}$, extractive content, and geometry of the particles that interfere in the bonding process and quality of the panels produced.
Regarding the use of particles obtained from the transformation of materials from furniture discards, which can contain MDF panels, particleboards and sawn wood, some characteristics are differentiated, such as the variation in density between wood of different species and between these woods and the panels. The panels are also produced with polymerized resin and paraffin, and have already undergone high temperature pressing process.

In view of the above, this research has the objective of evaluating the feasibility of using particles obtained from furniture discards, in a pure form and, in different mixed proportions of industrial particles of Pinus, as the raw material to produce particleboards.

\section{MATERIALAND METHODS}

The material that was object of this study was collected in the Curitiba region and consisted of discarded furniture used as: bedroom, living rooms and kitchen cabinets, as well as furniture components such as drawers, table tops, doors, shelves, bed bases, support structures and frames in general. Materials also contained metallic and plastic accessories, hinges, shelf supports, handles, nails, screws, and staples. The products used in the furniture were particleboards, MDF, hardboard, plywood, and sawn wood, with different finishes such as paints, wood veneers, plastic laminates and decorative papers (melamine film) and FF (finish foil).

All the collected material was processed in a crusher, equipped with an electromagnet for metal removal. The process was repeated twice for complete metal removal and chip reduction. All other components of the discards were shredded, but were not removed from the resulting material.

Industrial Pinus particles, urea-formaldehyde resin, paraffin emulsion and ammonium sulfate were also used as catalysts.

Both the chips obtained from furniture discards and the industrial Pinus particles were reprocessed twice in the hammer mill using sieves with meshes of $18 \mathrm{~mm}$ and $12 \mathrm{~mm}$. After this procedure, the particles were dried at medium moisture content of $3 \%$ and classified into "fine" sieves. From these particles, the density in bulk was determined, such as $\mathrm{pH}$ and total extractive content, aiming to characterize the material coming from furniture discards that were exposed to the varied conditions of the environment during its 
life cycle. The assays were performed according to adapted standards ABNT-NBR 6922 (ABNT, 1983), TAPPI 252 and TAPPI 204 (TAPPI, 2002), respectively. The same properties were also determined for industrial Pinus particles.

The experimental design consisted of six treatments, with a mixture of $10 \%, 25 \%, 50 \%$ and $75 \%$ of particles of furniture discarded with industrial particles of Pinus, and $100 \%$ of particles of each of these materials (Table 1).

The experimental panels were produced with nominal density of $0,70 \mathrm{~g} / \mathrm{cm}^{3}$ and dimensions of $500 \mathrm{x} 500 \mathrm{x}$ $13 \mathrm{~mm}$ (length, width, and thickness). The ureaformaldehyde resin was applied in the amount of $10 \%$ solids, basis dry weight of the particles, and $1 \%$ paraffin emulsion. The panels were pressed at a temperature of $140^{\circ} \mathrm{C}$, specific pressure of $4.0 \mathrm{MPa}$ and pressing time of 10 minutes. After pressing, the panels were squared and conditioned in a climatic chamber with a temperature of $20 \pm 3^{\circ} \mathrm{C}$ and relative humidity of 65 $\pm 5 \%$, until stabilization.

The quality of the panels was evaluated on the basis of their physical and mechanical properties, according to the test procedures described in the EN and ABNT standards: apparent density (EN 323), water absorption and swelling in thickness after 2 and 24 hours of immersion in water (EN 317), modulus of elasticity and rupture in static bending (EN 310), perpendicular traction (internal connection) to the surface of the panel (EN 319), resistance to screw removal at the surface and at the top (NBR $14810-3$ ).

Statistical analysis was performed according to a completely randomized design and the results were evaluated through analysis of variance (ANOVA), covariance analysis (ANCOVA) and Tukey test, at a 95\% confidence level.

Table1 - Experimental design.

Tabela1 - Delineamento experimental.

\begin{tabular}{lcr}
\hline Treatment & \multicolumn{2}{c}{ Composition of panels } \\
\cline { 2 - 3 } & $\begin{array}{c}\text { Furniture } \\
\text { discards (\%) }\end{array}$ & $\begin{array}{r}\text { Pinus } \\
\text { particles(\%) }\end{array}$ \\
\hline T1:10\% DM / 90\% P & 10 & 90 \\
T2:25\% DM / 75\% P & 25 & 75 \\
T3:50\% DM / 50\% P & 50 & 50 \\
T4:75\% DM / 25\% P & 75 & 25 \\
T5:100\% DM & 100 & 0 \\
T6:100\% P & 0 & 100 \\
DM: particles of furniture discards; P: particles of Pinus.
\end{tabular}

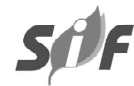

\section{RESULTS}

\subsection{Physical and chemical properties of wood particles}

The particles obtained from furniture discards presented a mean value of density bulk of $0,178 \mathrm{~g} /$ $\mathrm{cm}^{3}$, lower than the average value of $0,200 \mathrm{~g} / \mathrm{cm}^{3}$ obtained on the industrial Pinus particles (Table 2). These values should serve as reference in the compaction of the particles in the panel and may influence their physical and mechanical properties.

Regarding the chemical analyzes of the materials, the average $\mathrm{pH}$ value obtained for the furniture discards was 5,30 and 5,14 for the industrial particles of Pinus. As for total extractives, the average value was $7,93 \%$ and $6,18 \%$ for the respective materials.

\subsection{Physical properties of panels}

Mean panel density values ranged from 0,682 $\mathrm{g} / \mathrm{cm}^{3}$ for panels produced with $100 \%$ Pinus (T6) particles to $0,714 \mathrm{~g} / \mathrm{cm}^{3}$ for panels produced with $100 \%$ furniture discard particles (T5), The mean values were statistically different from each other. There were no significant differences between the means obtained for panels produced with mixture of different materials (Table 3 ).

The mean values of water absorption after 2 hours of immersion ranged from $12,34 \%$ for panels produced with $50 \%$ of furniture discards and $50 \%$ of Pinus (T3) to $19,28 \%$ for panels produced with $75 \%$ of particles of furniture discards and $25 \%$ of Pinus (T4), the mean values being statistically different from each other. There were no significant differences between the other treatments

For water absorption after 24 hours of immersion, the mean values varied from $34,75 \%$ for panels produced with $100 \%$ of particles Pinus (T6) to $42,68 \%$ for panels produced with $75 \%$ of furniture discards and $25 \%$ of Pinus (T4), the mean values being statistically different

Table 2 - Results of physical and chemical properties of the particles.

Tabela 2-Resultados das propriedades fisicas e químicas das particulas.

\begin{tabular}{lccc}
\hline Particles & $\mathrm{MEg}\left(\mathrm{g} / \mathrm{cm}^{3}\right)$ & $\mathrm{pH}$ & $\begin{array}{c}\text { Total Extracts } \\
(\%)\end{array}$ \\
\hline $\begin{array}{l}\text { Furniture } \\
\text { discards }\end{array}$ & 0,178 & 5,30 & 7,93 \\
Pinus & 0,200 & 5,14 & 6,18 \\
\hline
\end{tabular}

MEg: density bulk of the particles.

Revista Árvore. 2017;41(4):e410407 
Table 3 - Results of physical properties of the panels.

Tabela 3 - Resultados das propriedades físicas dos painéis.

\begin{tabular}{|c|c|c|c|c|c|}
\hline Treatment & $\mathrm{ME}\left(\mathrm{g} / \mathrm{cm}^{3}\right)$ & AA $2 \mathrm{~h}(\%)$ & AA $24 h(\%)$ & IE $2 \mathrm{~h}(\%)$ & IE $24 h(\%)$ \\
\hline$\overline{\mathrm{T} 1: 10 \% \mathrm{DM} / 90 \% \mathrm{P}}$ & $0,692^{\mathrm{ab}}$ & $13,09^{\mathrm{ab}}$ & $34,85^{a}$ & $4,82^{\mathrm{a}}$ & $14,19^{b}$ \\
\hline $\mathrm{T} 2: 25 \% \mathrm{DM} / 75 \% \mathrm{P}$ & $0,697^{\mathrm{abc}}$ & $16,02^{\mathrm{bc}}$ & $40,47^{\mathrm{bc}}$ & $5,54^{\mathrm{a}}$ & $14,78^{\mathrm{bc}}$ \\
\hline $\mathrm{T} 3: 50 \% \mathrm{DM} / 50 \% \mathrm{P}$ & $0,703^{\mathrm{abc}}$ & $12,34^{\mathrm{a}}$ & $42,09^{c}$ & $5,99^{\mathrm{a}}$ & $15,98^{\mathrm{c}}$ \\
\hline $\mathrm{T} 4: 75 \% \mathrm{DM} / 25 \% \mathrm{P}$ & $0,713^{\mathrm{bc}}$ & $19,28^{\mathrm{c}}$ & $42,68^{\mathrm{c}}$ & $7,34^{\mathrm{b}}$ & $15,60^{\mathrm{bc}}$ \\
\hline T5:100\% DM & $0,714^{\mathrm{c}}$ & $14,25^{\mathrm{ab}}$ & $37,26^{\mathrm{ab}}$ & $5,80^{\mathrm{a}}$ & $11,60^{\mathrm{a}}$ \\
\hline T6:100\% P & $0,682^{\mathrm{a}}$ & $14,97^{\mathrm{ab}}$ & $34,75^{\mathrm{a}}$ & $5,73^{\mathrm{a}}$ & $14,30^{\mathrm{b}}$ \\
\hline
\end{tabular}

DM: particles of furniture discards; P: industrial particles of Pinus. AA $2 \mathrm{~h}$ and AA $24 \mathrm{~h}$ : absorption of water after 2 and 24 hours of immersion; IE $2 \mathrm{~h}$ and IE 24h: swelling in thickness after 2 and 24 hours of immersion; Means followed by the same letter overlapped within the same column are statistically equal to each other at the $95 \%$ confidence level. Values adjusted by ANCOVA for an apparent density of 0,708 $\mathrm{g} / \mathrm{cm}^{3}$.

from each other. The treatments T1 $(10 \% \mathrm{DM} / 90 \% \mathrm{P})$, T5 (100\% DM) and T6 (100\% P) were the ones with the lowest values of water absorption after 24 hours of immersion.

The mean values of swelling in thickness after 2 hours of immersion in water varied from $4,82 \%$ for panels produced with $10 \%$ of furniture discards and $90 \%$ of Pinus (T1) to $7,34 \%$ for panels produced with $75 \%$ of furniture discards and $25 \%$ of Pinus (T4), the mean values being statistically different from each other. All other treatments presented mean values of water absorption $2 \mathrm{~h}$ statistically equivalent to each other, and lower in relation to treatment (T4).

For swelling in thickness after 24 hours of immersion in water, the mean values ranged from $11,60 \%$ for panels produced with $100 \%$ of furniture discards particles (T5) to $15,98 \%$ for panels produced with $50 \%$ particle of furniture discards and $50 \%$ of Pinus. The panels produced with $100 \%$ of furniture discards (T5) presented a statistically lower mean value in relation to the other treatments.

\subsection{Mechanical properties of panels}

Mean values of MOE ranged from 1.452 MPa for panels produced with $75 \%$ of furniture discards and $25 \%$ of Pinus (T4) to $1.956 \mathrm{MPa}$ for panels produced with $10 \%$ of furniture discards and $90 \%$ of Pinus (T1), the mean values being statistically different from each other. There were no significant differences between the other treatments (Table 4).

The mean values of MOR varied from 10.17 MPa for panels produced with $75 \%$ of furniture discards and $25 \%$ of Pinus (T4) to $13.10 \mathrm{MPa}$ for panels produced with $10 \%$ of furniture discards and $90 \%$ of Pinus (T1), the mean values being statistically different from each other. As verified for the MOE, significant differences between the other treatments were not observed for the MOR.

For internal bonding (LI), the mean values varied from $0,60 \mathrm{MPa}$ for panels produced with $100 \%$ of Pinus (T6) particles to $0,96 \mathrm{MPa}$ for panels produced with $10 \%$ of furniture discards and $90 \%$ of Pinus (T1), the mean values being statistically different from each other. Higher values were obtained for panels produced with $10 \%$ and $25 \%$ of furniture discards with $90 \%$ and $75 \%$ of Pinus particles (T1 and T2), respectively, being statistically superior in comparison to the other treatments.

The results of MOE, MOR and internal bond indicate a reduction in the average values of these properties with the gradual increase of the percentages of mixtures of particles of furniture discard, up to the proportion of $75 \%$.

The mean values of screw tear resistance at the panel surface ranged from $1.033 \mathrm{~N}$ for panels produced with $25 \%$ mobile discards and $75 \%$ Pinus (T2) to 1.185 $\mathrm{N}$ for panels produced with $10 \%$ discards of furniture and $90 \%$ of Pinus (T1). Meanwhile, for bolt pulling resistance at the top, mean values ranged from 945 $\mathrm{N}$ for panels produced with $10 \%$ mobile discards and 90\% Pinus (T1) to $1.127 \mathrm{~N}$ for panels produced with $50 \%$ particle of furniture discards and $50 \%$ of Pinus (T3). For the removal of screws at the surface and at the top, no statistically significant differences were found between the means of the treatments.

\section{DISCUSSION}

\subsection{Physical and chemical properties of wood particles}

The results of the bulk density revealed that the discarded furniture particles have a lower bulk density than the Pinus particles. This difference may be related 
Table4 - Results of mechanical properties of the panels. Tabela 4 - Resultados das propriedades mecânicas dos painéis.

\begin{tabular}{|c|c|c|c|c|c|}
\hline Treatment & MOE(MPa) & MOR(MPa) & LI(MPa) & APS(N) & $\operatorname{APT}(\mathrm{N})$ \\
\hline$\overline{\mathrm{T} 1: 10 \% \mathrm{DM} / 90 \% \mathrm{P}}$ & $1.956^{\mathrm{b}}$ & $13,10^{\mathrm{b}}$ & $0,96^{\mathrm{b}}$ & $1.185^{\mathrm{a}}$ & $945^{a}$ \\
\hline $\mathrm{T} 2: 25 \% \mathrm{DM} / 75 \% \mathrm{P}$ & $1.804^{\mathrm{ab}}$ & $12,21^{\mathrm{ab}}$ & $0,93^{\mathrm{b}}$ & $1.033^{\mathrm{a}}$ & $1.034^{\mathrm{a}}$ \\
\hline $\mathrm{T} 3: 50 \% \mathrm{DM} / 50 \% \mathrm{P}$ & $1.689^{\mathrm{ab}}$ & $11,97^{\mathrm{ab}}$ & $0,72^{\mathrm{a}}$ & $1.148^{\mathrm{a}}$ & $1.127^{\mathrm{a}}$ \\
\hline $\mathrm{T} 4: 75 \% \mathrm{DM} / 25 \% \mathrm{P}$ & $1.452^{\mathrm{a}}$ & $10,17^{\mathrm{a}}$ & $0,66^{\mathrm{a}}$ & $1.093^{\mathrm{a}}$ & $982^{\mathrm{a}}$ \\
\hline $\mathrm{T} 5: 100 \% \mathrm{DM}$ & $1.701^{\mathrm{ab}}$ & $11,36^{\mathrm{ab}}$ & $0,75^{\mathrm{a}}$ & $1.095^{\mathrm{a}}$ & $1.006^{\mathrm{a}}$ \\
\hline T6:100\% P & $1.815^{\mathrm{ab}}$ & $12,94^{\mathrm{ab}}$ & $0,60^{\mathrm{a}}$ & $1.067^{\mathrm{a}}$ & $1.043^{\mathrm{a}}$ \\
\hline
\end{tabular}

DM: particles of furniture discards; P: industrial particles of Pinus. MOE: Modulus of elasticity; MOR: Modulus of rupture; LI: Internal bonding; APS: Surface screw removal; APT: Top screw removal. Means followed by the same letter overlapped within the same column are statistically equal to each other at the $95 \%$ confidence level. Specific density values for static bending tests: $0,672 \mathrm{~g} / \mathrm{cm}^{3} ; \mathrm{LI}$ adjusted by ANCOVA: $0,733 \mathrm{~g} / \mathrm{cm}^{3}$; Screw Pullout: $0,684 \mathrm{~g} / \mathrm{cm}^{3}$.

to the higher density and higher compaction of the products from furniture discards due to the hot-pressing process, resulting in greater difficulties to the conditions of reprocessing at the hammer mill, generating particles of larger dimensions. For Garcia et al. (2013) the larger the particle size the smaller the density in bulk, because the larger the voids between them will be. Another possible justification, besides the influence of the voids between the particles, would be the difference between the densities of the discarding materials. As a reference, Azambuja (2015) obtained for particles from construction and demolition waste the following values of bulk density for different products: Pinus particles: 0,183 g/cm ${ }^{3}$; MDF: 0,113 g/ $\mathrm{cm}^{3}$; Agglomerates: 0,275 g/ $\mathrm{cm}^{3}$; Compensated: $0,238 \mathrm{~g} / \mathrm{cm}^{3}$; And sawn wood: $0,249 \mathrm{~g} / \mathrm{cm}^{3}$.

Regarding $\mathrm{pH}$, the results obtained for both the furniture discards and the industrial Pinus particles are within the range presented in the literature. Moslemi (1974) mentions $\mathrm{pH}$ values for wood between 3 and 6; Trianoski (2012) obtained for wood of Pinus taeda $\mathrm{pH}$ of 4,64 and for species of tropical pinus, from 4,17 to 4,61 . Higher $\mathrm{pH}$ values are usually beneficial for the production of panels, for their lower effect on the pre-curing of the urea-formaldehyde resin during the panel pressing process.

The total extractive values obtained for the two types of materials analyzed were within the range of $5 \pm 3 \%$ for conifers, as mentioned by Fengel and Wegener (1989), and below the maximum value of 10\% cited by Sjöströn (1981). In the study by Trianoski (2012), the average results of the total extractives ranged from $3,34 \%$ to $8,82 \%$, for different tropical pine species.

\subsection{Physical properties of panels}

The differences between the densities of the panels, as well as the variation between the values obtained in relation to the nominal density, can be attributed to the manufacture of the panels in the laboratory, where a variation of the concentration and distribution of the particles in the forming box may occur during the manual deposition.

It was noticeable that density increased with the increase in the proportion of the amount of discarded furniture particles in the mixture used in the manufacture of the panels. This may be a consequence of the higher amount of cured resin solids present in these particles, influencing the lower return in thickness, upon release of the pressure and the climatisation process of the panels, reducing volume expansion and increasing the density of the panels.

The results of water absorption and swelling in thickness indicated the statistical equivalence between the averages obtained for panels produced with $100 \%$ of furniture discards and industrial Pinus particles, except for the swelling in thickness after 24 hours of immersion. As for the different mixing proportions, the possibility of inclusion of up to $75 \%$ of furniture discards with Pinus was observed, with promising results for particleboards that require dimensional stability.

Weber and Iwakiri (2015) report in their work the favorable aspects of the use of residues of particleboards and MDF in the production of new particulate panels, due to the presence of paraffin in its original composition, which can positively influence the dimensional stability of panels produced. The greater presence of resin and paraffin residuals from the original panels contributed to the reduction of water absorption and swelling in thickness of the evaluated panels.

The panels of all the treatments met the requirement of norm NBR 14810 (ABNT, 2006b) that establishes for swelling in thickness, after 2 hours of immersion in water, the maximum value of $8 \%$. Regarding swelling in thickness, after 24 hours of immersion, all treatments 
presented values lower than $18 \%$ as established by NBR 14810 (ABNT, 2014a).

The water absorption results obtained in this research were satisfactory in comparison to some references present in literature. Naumann et al. (2008) found for particleboards of Eucalyptus urophylla and Schizolobium amazonicum, 24 hours absorption values of $97,2 \%$ and $117,9 \%$, respectively. Iwakiri et al. (1996) found particleboards of Pinus taeda and Eucalyptus dunnii, 75,04\% and 80,05\%, respectively. The results obtained in this research were well below the values of $20,24 \%$ and $20,43 \%$ obtained by Dacosta et al. (2005) for panels produced with processing residues of Pinus elliottii with resin content of $8 \%$ and $12 \%$, respectively. Iwakiri et al. (1996) found for panels of Pinus taeda and Eucalyptus dunnii, values of 30,50\% and 35,09\%.

\subsection{Mechanical properties of panels}

The MOE and MOR values obtained for the panels of all treatments produced with furniture discards were statistically equivalent in comparison to the control panels produced with industrial Pinus particles. Likewise, for internal bonding, the panels of all the treatments produced with particles obtained from furniture discards presented values statistically equal or superior in comparison to the panels of Pinus.

Except for panels produced with $75 \%$ of furniture discards and $25 \%$ of Pinus particles, all other treatments had a mean MOE above the minimum value of 1.600 MPa established by EN 312: 2003. Regarding MOR, only the T1 treatment, produced with $10 \%$ of furniture discards and $90 \%$ of Pinus, met the minimum requirement of $13 \mathrm{MPa}$, according to that standard. However, the averages obtained for the treatments with up to $50 \%$ mix of discarded furniture particles and the rest of Pinus particles, as well as panels produced with $100 \%$ of discarded furniture particles, are statistically equivalent to the approved treatment. The results obtained for internal bonding were fully satisfactory, considering that all treatments had averages higher than the minimum standard requirement of $0,35 \mathrm{MPa}$.

The results of mechanical properties obtained in this work were satisfactory when compared to some results presented in the literature. Weber and Iwakiri (2015), found for particleboards produced with mixtures of particles obtained from particleboard, offset and MDF processing residues, MOE and MOR values of
1.438 MPa and 8,44 MPa, respectively. Azambuja (2015) obtained for panels produced with $25 \%$ and $50 \%$ of particles obtained from building and demolition waste mixed with Pinus particles, values of $1.446 \mathrm{MPa}$ and $1.352 \mathrm{MPa}$, and of 8,09 and 6,97 $\mathrm{MPa}$, respectively. As for internal bonding, Colli et al. (2010), found for particleboards produced with Schizolobium amazonicum average value of 0,22 MPa. Meanwhile, Vital et al. (1974) found for particleboards of Virola spp., with compaction ratio of 1,2: 1.0 (low) and 1,6:1.0 (high), values of $0,48 \mathrm{MPa}$ and 0,65 $\mathrm{MPa}$, respectively.

The average values for screw pulling at the surface and at the top of the panels were higher than the minimum requirements of $1.020 \mathrm{~N}$ and $800 \mathrm{~N}$, established by NBR 14810 (ABNT, 2006).

The screw pulling results obtained were compatible in comparison to some studies. Weber (2011) found, for particleboards with a density of $0,80 \mathrm{~g} / \mathrm{cm}^{3}$ and $10 \%$ resin content, produced with mixtures of particles obtained from particleboard, offset and MDF processing residues, values from $810 \mathrm{~N}$ to $1.200 \mathrm{~N}$ for screw pulling at the surface and from $591 \mathrm{~N}$ to $1.345 \mathrm{~N}$ at the top. In a paper published by Azambuja (2015), panels produced with a density of $0,75 \mathrm{~g} / \mathrm{cm}^{3}$ and $8 \%$ of UF resin content, composed by mixing $25 \%$ and $50 \%$ of demolition particles in a mixture with Pinus particles, presented better results for screw pulling at the surface, $1.177 \mathrm{~N}$ and $1.198 \mathrm{~N}$, respectively. For the screw removal at the top, the best results were, respectively, 1.122 $\mathrm{N}$ and $1.132 \mathrm{~N}$.

\section{CONCLUSION}

The particles obtained from furniture discards presented lower bulk density in relation to the industrial Pinus particles, which did not significantly influence the properties of the particleboards.

Also, higher levels of total extractives of the furniture discards in relation to the Pinus particles did not influence the results of the properties of the panels produced.

The values of the physical and mechanical properties of the panels were within the values recommended by NBR and EN standards, except for MOE and MOR, regarding panels with mixtures of $75 \%$ of discarded furniture particles and $25 \%$ of Pinus, demonstrating the potential of using particles from discarded furniture for particleboard production. 


\section{REFERENCES}

Associação Brasileira de Normas Técnicas ABNT. NBR 6922. Rio de Janeiro: 1983.

Associação Brasileira de Normas Técnicas ABNT. NBR 14810 - 2-Chapas de madeira aglomerada - Parte 2 - Requisitos. Rio de Janeiro: 2006a.

Associação Brasileira de Normas Técnicas ABNT.. NBR 14810 - 2 - Chapas de madeira aglomerada - Parte 2 - Requisitos. Rio de Janeiro: 2014 .

Associação Brasileira de Normas Técnicas ABNT. NBR 14810 - 3 - Chapas de madeira aglomerada - Parte 3 - Métodos de Ensaio. Rio de Janeiro: 2006b.

Azambuja RR. Aproveitamento de resíduos de construção e demolição para produção de painéis aglomerados [dissertação] Curitiba: Universidade Federal do Paraná: 2015.

Colli A, Vital BR, Carneiro ACO, Silva JC, Carvalho ANML, Della Lucia RM. Propriedades de chapas fabricadas com partículas de madeira de paricá (Schizolobium amazonicum Huber ex. Ducke) e fibras de coco (cocos mucifera L.) Revista Árvore. 2010;34(2):333-8.

Dacosta LPE, Haselein CR, Santini EJ, Schneider PR, Calegari L. Propriedades físicas de chapas de partículas aglomeradas fabricadas com resíduos do processamento mecânico da madeira de Pinus elliotii Engelm. Ciência Florestal. 2005;15 (4):421-9.

European Committee for Standardization. EN 310. Determination of modulus of elasticity in bending and of bending strength. Brussels: 2002.

European Committee for Standardization. EN 312. Particleboards - Specifications. Brussels: 2003.

European Committee for Standardization.. EN 317. Determination of swelling in thickness after immersion in water. Brussels: 2002.

European Committee for Standardization. EN 319. Determination of perpendicular tension strength. Brussels, 2002.
European Committee for Standardization. EN 323. Determination of board density. Brussels: 2002.

Fengel D, Wegener G. Wood chemistry, ultrastructure reactions. Berlin: Springer Verlag; 1989. 612p.

Garcia D, Caraschi JC, Ventorim G. Caracterização energética de pellets de madeira. Revista da Madeira. 2013;135 (maio): 43-7.

Iwakiri S, Latorraca JVF, Silva DA, Gabardo JL, Klitzke RJ, Fofano A, Fabrowski F, Interanmense MT. Produção de chapas de madeira aglomerada de Pinus elliottii (Engelm) and Eucalyptus dunnii (Maid). Agrárias. 1996;15:33-41.

Iwakiri S, Silva JC, Silva JRM, Alves CR, Puehringer CA. Produção de compensados de Pinus taeda L. e Pinus oocarpa Schiede com diferentes formulações de Uréia-Formaldeído. Revista Árvore. 2002;26(3):371-5.

Iwakiri S, Vianez BF, Weber C, Trianoski R, Almeida VC. Avaliação das propriedades de painéis aglomerados produzidos com resíduos de serrarias de nove espécies de madeiras tropicais da Amazônia. Acta Amazônica. 2012;42:59-64.

Mickleburgh S, Magin G. Timber Recycling Opportunities in the UK. A summary of presentations given at four workshops in Cambridge, Manchester, Birmingham and Bristol. Fauna \& Flora International. 2003;1:19-24.

Maloney TM. Modern particleboard \& dryprocess fiberboard manufacturing. San Francisco: Miller Freeman; 1993. 689p.

Moslemi AA. Particleboard. London: Southern Illinois University Press; 1974. 245p.

Naumann RB, Vital BR, Carneiro ACO, Della Lucia RM, Silva JC, Carvalho AMML et al. Propriedades de chapas fabricadas com partículas de madeira de Eucalyptus urophylla S.T. Blake e de Schizolobium amazonicum Herb. Revista Árvore. 2008;32:1143-50.

Sjöström. E. Wood chemistry fundamentals and applications. New York: Academic Press; 1981. 223p.

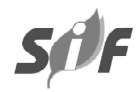

Revista Árvore. 2017;41(4):e410407 
Testing Procedures of Technical Association of the Pulp and Paper Industry - TAPPI. TAPPI Standard Method [Cd-Rom]) Atlanta: 2002. (Coletânea de Normas)

Trianoski R. Avaliação da qualidade da madeira de espécies de Pinus tropicais por meio de métodos convencionais e não destrutivos [tese]. Curitiba: Universidade Federal do Paraná; 2012.
Vital BR, Lehmann WF, Boone RS. How species and board densities affect properties of exotic hardwood particleboards. Forest Products Journal. 1974;24:37-45.

Weber C, Iwakiri S. Utilização de resíduos de compensados, MDF e MDP para produção de painéis aglomerados. Ciência Florestal. 2015;25:405-13. 